\title{
On the constitutive effects of contingent associations
}

\section{Matthias Thiemann}

Sciences Po, France

Neoliberalism, at least in the US, is here to stay and even seems amplified after the crisis of 2008. In this sense, Konings' (2018) theoretical intervention against a moralistic critique of neoliberal capitalism, which decries its speculative character as its main default, is a welcome correction. Instead, he suggests replacing this approach with an immanent critique of the way neoliberal governance handles the speculative character of capitalism. In doing so, he has drawn on thinkers as diverse as Marx and Luhmann, engaging their most original ideas without being deterred by some of their seeming incompatibilities. ${ }^{1}$ His syntheses are often courageous and lucid, but at the same time, the form of the book generates frustration; the text is very essayistic, laying out a promising line of thought, but without giving pride of place to those criticized or the arguments they put forward. ${ }^{2}$

In Capital and Time, Konings departs decisively from the Marxist understanding of capital based on the labor theory of value, which includes time in the very essence of capital (as congealed labor time), but also from all Polanyian attempts to contrast speculative finance capitalism, which has been dis-embedded from society and endangers the livelihood of the population, with an industrial one based on real production. ${ }^{3}$ He motivates this intervention with an empirical puzzle, asking why the left went so wrong in its expectations post-crisis. Instead of an end to speculation, a re-embedding of markets, and a return of Keynesianism, it is the persistence of neoliberalism and its continuing support of financial expansion that requires explanation. His starting point is a rejection of the Polanyian critique of capitalism. The latter sees financialized capitalism as an unwarranted deviation from fundamentals that needs to be reined in. According to Konings, this position entails a problematic, moralistic relationship to speculation, which can be traced back to Aristotle's critique of chrematistics the lending of money for the simple purpose of making more money.

The problem with this stance, Konings tell us, is that it engenders a fundamentalist understanding of value, which means that analysts are forced into assuming an elastic relationship between fundamental values and speculative deviations. Such an understanding of capitalism points to external standards of value, which, however, cannot be determined externally to the system. As a result, these critiques engender an ontological misunderstanding of capitalism, for investment in capitalism is always speculative. So far, so Keynes, but how

\section{Corresponding author:}

Matthias Thiemann, Sciences Po, Centre d'études Européens, 27 Rue Saint Guillaume, 75007 Paris, France.

Email: matthias.thiemann@sciencespo.fr 
does this problematic relate to neoliberalism and its continued rule? Konings' argument here is that this misinterpretation of capitalism leads to a theoretical dead-end, as one fails to see how the speculative moment has been actively used to restructure American capitalism via the interventions of neoliberal governance. That is to say, one fails to appreciate how speculative interventions, born of the radical rejection in neoliberal thought of rational constructivism based on objective standards (i.e., social engineering), have shaped and continue to shape financial governance in the US. ${ }^{4}$ To make these points, the book pursues three themes: the speculative nature of economic value, the logic of banking as a normalizing force in the logic of risk, and the role of speculation and risk in neoliberal governance (Konings, 2018: 4).

What, then, are the main takeaways from this theoretical intervention? First of all, it tells us that to understand the expansion of finance, we need an understanding of money and finance that overcomes the distinction between real value and speculation. Instead of an elastic notion of value which dictates a potentially tense relationship between real valuecreation and speculation, Konings builds his account on a plastic notion of value, which starts from the dictum that all investment is speculative and that pursuing a fundamentalist notion of value is a pipedream, a theoretical cul-de-sac which leads nowhere but into irresolvable paradoxes (such as money having value and no value at all). Hence, instead of excluding these paradoxes and then being paralyzed by their inevitable reappearance, Konings suggests with Luhmann that we put this paradox and its temporalization at the core of our theoretical endeavor. This is the relationship of capital and time he has in mind, a clarification which unfortunately only appears in the book's last pages: investment is always speculative, you engage in uncertain investments; those investments bind subjects to particular wagers on the future, and those so bound will seek to generate the conditions for the fulfillment of these wagers (for a very similar theorization, see Pistor, 2013). Wagers on the future are therefore the associations that link society together as a self-organizing system; it is this web of promissory notes that generates plasticity as contingent associations become constitutive. Perry Mehrling (2011) expresses very much the same 'poetic view' of society.

On this view, the world tumbles forward in an incalculable manner, in which calculations are indeed made, but can only serve as provisional guidance given the mutual interdependence of investment decisions. As Minsky so beautifully put it, financial society is "a decentralized system in which a myriad of interdependent agents make decisions whose impacts are aggregated into outcomes that emerge over a range of tomorrows" (quoted in Konings, 2018: 101). This Keynesian approach to money expresses itself in the dictum that money is the least risky bet in a game of investment which is always in motion, can never be put on hold, and which requires constant action. Konings' understanding of power emerges immanently from this understanding of the plasticity of value, based on contingent associations and the forces that drive their patterning. Power emerges from the capacity of actors to make their promises central to the fulfillment of other's actors promises, thereby gaining leverage over these other actors' decisions. The powerful, such as the banks, use leverage to ensure that their promises are fulfilled, or at least somehow 'made whole'. This view of power reaches its apex, when, as Konings explains, attempts to channel future developments in certain ways lead to a foreclosing of the future, such as when there is no alternative' but to save the banks at the central nodal points of the system (cf. Esposito, 2011). It is hence their central position within a network of promises that provides banks with their power or leverage.

Based on these insights, Konings (2018: 61) seeks to construct a way forward by formulating what he calls a "non-essentializing economism" - an approach to observable financial activities without an external normative critique or appeal to unidentifiable 
fundamentals. In this endeavor, he puts great emphasis on the ways in which mainstream economics sanitizes the paradoxes of money and monetary economies, on the one hand acknowledging the socially constructed nature of the economy while on the other hand postulating the conditions under which money can have a mere representational character. This is an important insight, and one through which the history of twentieth-century economics can be re-read as an oscillation between the ontology of a real economy that uses money for convenience and a monetary economy that derives its instability from money. ${ }^{5}$ An interesting insight that Konings could have explored somewhat further is that it is the role of governance to guarantee this neutrality of money. Beginning with Adam Smith's real bill doctrine and up until Knut Wicksell's notion of the natural rate of interest, the actions of the central node within the network of promises to pay, namely the central bank, are supposed to be directed toward achieving this transformation, i.e., keeping the status of money neutral.

Now, how does neoliberalism relate to this? In Capital and Time, neoliberalism is clearly identified with Hayek and his social thought. ${ }^{6}$ Konings' main contention is that neoliberal governance is a governance which itself is based on the conviction that no external standpoint of observation can be found, and that the pathways towards rational constructivism are forever barred. Instead, neoliberal governance on the one hand seeks to encourage in its subjects a stance that accepts the necessity of speculation, which invades ever more spheres of social life. ${ }^{7}$ On the other hand, it is a mode of governance that seeks to make crises productive, and which engages new methods of governing in an experimental manner, not because it believes in their professed notions, but instead because it believes in the productive potential of the crises they can evoke. This is exemplified through the Volcker shock, which engages monetarism as a means of resolving inflationary pressures accumulated during the 1970s.

At this point, the book's overly brief treatment of historical events becomes problematic. In an elliptic, apodictic style, contingent choices are transformed into goal-oriented activity, where the reader is informed that "such a liberation of banking dynamics was the point of the turn to monetarism" (Konings, 2018: 108), without any further justification. Setting shadow banks free to pursue their business might have been the effect of the Volcker shock, but was it also its goal? These formulations sit uneasily with Konings' own emphasis on speculation and the necessary lack of knowledge regarding the consequences of policy intervention. Existing scholarship, including some of Konings' own interventions (e.g., Krippner, 2007; Konings, 2007), emphasizes the unplanned, trial-and-error nature of a policy apparatus reaching its limits; so how, then, can monetarism have been a plan so well made and executed? The problem posed by the brevity of coverage continues in his discussion of post-crisis developments. While Konings' main contention is that not much has changed post-crisis, he devotes remarkably little effort to detailing post-crisis interventions to substantiate this claim. To him, central bankers have mainly focused on inciting the capacity for self-organization of the financial sector, while at the same time increasing their capacities for intervention regarding too-big-to-fail banks.

This characterization can be put into question if we look more closely at the treatment of 'too big to fail' banks post-crisis, which not only entails new capital surcharges for global systemic financial institutions, but also requirements to create 'living wills', as well as decisions to increase the loss-absorbing capacity of large banks. While the enlarged lossabsorbing capacity is supposed to make large banks more resilient, resolution plans (or 'living wills') are supposed to facilitate the resolution of large banks, thereby ending their 'too big to fail' status. One can characterize this as an ordoliberal pipedream of recreating a direct match between profits and entrepreneurial responsibility, or of reinstating market discipline and of 
thereby ending 'too big to fail', but one cannot simply ignore it. Indeed, Basel III is very much driven by a desire to reinstate this symmetry (Biebricher, 2012).

Even if one integrates ordoliberalism into the neoliberal fold (which is a step Konings does not seem willing to take), a larger question remains: when would neoliberalism be over? And what about its alternatives? As every mode of governance is perishable, it would be interesting to see him lay out some kind of conditions for its end. Post-crisis, a different way of seeing finance and of intervening in finance has begun to gain currency (e.g. Adrian et al., 2013), and while active intervention is the most constrained in the US due to a missing mandate for the Fed on this issue, Konings still risks overlooking incipient shifts, such as a changed outlook on systemic risk, which is inherent in the Systemic Risk Monitoring Framework of the Federal Reserve. The sole focus on the US possibly allows such an omission, but it also leads to a neglect of possible challengers to the dominant governance paradigm. Neoliberal governance mirrors the speculative investment of capital in that it engages in speculative attempts to solve governance problems. A clear counter project would be the attempt to direct investment and the evolution of the financial system, an approach arguably taken in China and increasingly in Europe. How does such an industrial policy approach relate to neoliberal governance? And what are its prospects in the US?

A further weakness in the book is that the status of agents and agency in the evolution of neoliberal governance is not clear. ${ }^{8}$ Questions arise, for example, as to the consciousness of agents as they pursue certain policies, and these are not resolved in the text. But for the limit case of crisis management, in which contingency and necessity come together in the lender of last resort function, the role remains underspecified. This would not be a problem if agency and agents did not figure in Konings' theoretical model, but if that were the case, then what exactly would drive the persistence of neoliberal governance? On the other hand, ascribing willful agency to Volcker and arguing that he knew what he was doing risks relapsing behind existing literature, which depicts Volcker as a reluctant neoliberal. The brevity of the account can under no circumstances do justice to this question. In contrast, with respect to Greenspan, who is only referenced in connection with his official discourse maintaining the neutrality of money, recent literature shows how much more aware Greenspan was of the distorting effects of finance on the economy, as well as how he clung to a Schumpeterian notion of creative destruction (Mallaby, 2016; Hartmann, 2015).

This is an under-theorized point in the book, especially when repeated reference to Luhmann seems to suggest a doing-away with agency - after all, Luhmann was clearly opposed to any theory of agency. But then again, Konings' theoretical stance is never clarified; what is clear is that he rejects a simple story of agents becoming convinced of the neoliberal project. Instead, norms seem to play a central role, such as the norm of the entrepreneurial self, the willingness in neoliberalism to subject individuals to the consequences of this entrepreneurialism, as well as the embrace of speculative interventions to resolve governance dilemmas. But neither the evolution of norms nor their material underpinnings are clearly spelled out. While different practices of banking are acknowledged (for example, when contrasting the UK system of discounting trade bills and the US system of long term credit based on liquid security markets), these are not theorized or even included in the potential for alternative configurations of finance. In this respect, the book suffers in several instances from apodictic statements, which seem to reify the power positions of banks, and are then backtracked on through references to the historical evolution of banking and its imbrication with the state. Historical norms at the central node of the system, i.e. the central bank, have changed over time (e.g., from leaning against the wind to cleaning up the mess afterwards), but how and why these norms change is difficult to answer using Konings' account. ${ }^{9}$ 
Nevertheless, and despite these questions, this is an important book. It is not a convenient or easy read, but it is a rewarding one. The essayistic style of the manuscript requires the reader to have patience, as key concepts such as 'neoliberal reason' are not defined ex ante. And yet clarity is gained over the course of the book, as questions that arise in one chapter are answered in another. In addition, one cannot but admire the text for the intermittent clarity, cohesion, and fertility of the line of thought proposed by the author. His reading of Luhmann as a theorist of associations and his notion of plastic value are major theoretical breakthroughs.

In the end, openly or not, this is a venture by a theoretical entrepreneur who has engaged in an extraordinary wager, bringing together particular themes and traditions, including Marxian value-form analysis and a Luhmannian analysis of system evolution, which he combines with a Minskyan analysis of capitalism and uses to sketch out the beginnings of new, 'non-essentialist economism'. In this sense, the author follows in his critical endeavor the epistemological and ontological commitment expressed in his analysis of capitalism, in which any (theoretical) investment is an act of speculation, which gains validity by inscribing itself into a larger network of (analytical) promises. Given the impossibility of discerning externally valid criteria for critique, he is making a speculative investment with his own proposal, hoping that others find it useful for their own speculative venturing in the theoretical terrain. Given the clarity of many of his innovations, one can only hope that this critique's potential to, in the Luhmannian sense, irritate other observers, generates plenty of theoretical follow-ups.

\section{Notes}

1. I am thinking here in particular of the derision that Luhmann expressed for the distinction between capital and labor, which he saw as outmoded and unfit for contemporary times.

2. Given the book's brevity and lack of footnotes, as well as the small number of explicit references in the text, the reader is forced to take much of Konings' statements at face value, at least until inspection of the sources criticized. This inevitably happens when an author synthesizes their opponents' views, yet here the dearth of supporting materials is particularly remarkable.

3. Who exactly is presenting these views is never really clarified, although at different points, Konings points to authors like Wolfgang Streeck, Eric Helleiner and Geoffrey Underhill.

4. While there is an immediate plausibility to investigating the case of US capitalism, Konings never explains his case selection, nor how it relates to other countries, evoking an image of an uncritical US centrism, a strange fact for a Dutch scholar, who completed his PhD in Canada and teaches in Australia. Doing so, however, would help foreground important questions, such as how to theorize the link between US capitalism and the evolution of other national economies.

5. An interesting follow-up question would ask why attempts to relegate money to a 'veil' in economics gathered so much momentum. Some first answers can be found in Patnaik (2009).

6. This choice is not really justified, despite deviating from a broader literature that uses the term in a much broader fashion, including ordoliberal thought (as in Mirowski and Plehwe, 2013).

7. The most fertile and powerful example in this respect is the notion of human capital, and specifically how it transforms the positioning of the subject to itself, creating a need to make speculative investments into skills demanded by the labor market. Student debt and austerity are the other side of the coin, asking the subject to subjugate itself to the needs of speculation.

8. In a way, Konings risks overdrawing the continuity between Volcker and Greenspan, who represent two very different stances on the evolution of the shadow banking system: whereas Volcker was 
highly critical of bank-based shadow banking activities, such as the issuance of Asset-Backed Commercial Papers, Greenspan was openly supportive of these developments. See Thiemann (2018).

9. One first suggestion, borrowed from Luhmann, might be to distinguish between those norms that are held despite empirical experience, and those others that are continually updated to fit it.

\section{References}

Adrian, T., Covitz, D. and Liang, N. (2013) Financial stability monitoring. Federal Reserve Bank of New York Staff Reports, no. 601. Available at:

$<$ https://www.newyorkfed.org/research/economists/medialibrary/media/research/staff_reports/ sr601.pdf>. Accessed 5 September 2018.

Biebricher, T. (2012) Neoliberalismus zur Einführung. Hamburg: Junius-Verlag.

Esposito, E. (2011) The Future of Futures: The Time of Money in Finance and Society. Cheltenham:

Edward Elgar.

Hartmann, D. (2015) Krisen - Kämpfe - Kriege, Band I: Alan Greenspans endloser "Tsunami " - eine Angriffswelle zur Erneuerung kapitalistischer Macht. Berlin: Assoziation A.

Konings, M. (2007) The institutional foundations of US structural power in international finance: From the re-emergence of global finance to the monetarist turn. Review of International Political Economy, 15(1): 35-61.

Konings, M. (2018) Capital and Time: For a New Critique of Neoliberal Reason. Stanford, CA: Stanford University Press.

Krippner, G. (2007) The making of US monetary policy: Central bank transparency and the neoliberal dilemma. Theory and Society, 36(6): 477-513.

Mallaby, S. (2016) The Man Who Knew: The Life and Times of Alan Greenspan. London: Bloomsbury. Mehrling, P. (2011) The New Lombard Street: How the Fed Become the Dealer of Last Resort. Princeton, NJ: Princeton University Press.

Mirowski, P. and Plehwe, D. (eds.) (2013) The Road from Mont Pèlerin: The Making of the Neoliberal Thought Collective. Harvard, MA: Harvard University Press.

Patnaik, P. (2009) The Value of Money. New York, NY: Columbia University Press.

Pistor, K. (2013) A legal theory of finance. Journal of Comparative Economics, 41(2): 315-30.

Thiemann, M. (2018) The Growth of Shadow Banking: A Comparative Institutional Analysis. Cambridge: Cambridge University Press. 